\title{
Nitrogen-doped black titania for high performance supercapacitors
}

\author{
Chongyin Yang ${ }^{1}$, Xin Wang ${ }^{4}$, Wujie Dong ${ }^{1}$, I-Wei Chen ${ }^{2}$, Zhou Wang ${ }^{1}$, Jijian Xu ${ }^{1}$, Tianquan Lin ${ }^{1}$, \\ Hui $\mathrm{Gu}^{1}$ and Fuqiang Huang ${ }^{1,3^{*}}$
}

\begin{abstract}
For energy storage system, it is still a huge challenge to achieve high energy density and high power density simultaneously. One potential solution is to fabricate electrochemical capacitors (ECs), which store electric energy through surface ion adsorption or redox reactions. Here we report a new electrode material, heavy nitrogen-doped (9.29 at.\%) black titania $\left(\mathrm{TiO}_{2-x}: \mathrm{N}\right)$. This unique hybrid material, consisting of conductive amorphous shells supported on nanocrystalline cores, has rapid $\mathrm{N}$-mediated redox reaction $\left(\mathrm{TiO}_{2-x} \mathrm{~N}_{\mathrm{y}}+z \mathrm{H}^{+}+z \mathrm{e}^{-} \leftrightarrow \mathrm{TiO}_{2-x} \mathrm{~N}_{y} \mathrm{H}_{z}\right)$, especially in acidic solutions, providing a specific capacitance of $750 \mathrm{~F} \mathrm{~g}^{-1}$ at $2 \mathrm{mV} \mathrm{s}^{-1}$ $\left(707 \mathrm{~F} \mathrm{~g}^{-1}\right.$ at $\left.1 \mathrm{~A} \mathrm{~g}^{-1}\right)$, great rate capability $\left(503 \mathrm{Fg}^{-1}\right.$ at $20 \mathrm{~A} \mathrm{~g}^{-1}$ ), and maintain stable after initial fading. Being a new developed supercapacitor material, nitrogen-doped black titania may revive the oxide-based supercapacitors.
\end{abstract}

Keywords: black titania, supercapacitor, nitrogen-dopant, Nmediated redox reactions

\section{INTRODUCTION}

Transition metal oxides have been extensively studied as potential electrode materials. In supercapacitors, they accept ion adsorption as in electrochemical double-layer capacitors; in addition, they store energy via cation redox, like batteries but just on surface [1]. However, such electrodes except for $\mathrm{RuO}_{2}$ cannot serve as both cathode and anode. Moreover, their power and energy densities as well as endurance still fall short of the requirements for practical electrochemical capacitor (EC) applications [2]. Recently, we demonstrated nitrogen doping can activate unexpectedly large, fast redox activities in few-layer car- bon [3], which otherwise is electrochemically inert and exhibits only electrical double-layer capacitance (EDLC). Like graphene, many partially reduced transition metal oxides feature excellent conductivity. Therefore, we hypothesized that a similar approach could also convert transition metal oxides into promising EC materials. Specifically, we suspect that an anionic network with $\mathrm{N}^{3-}$ substituting $\mathrm{O}^{2-}$ may allow enhanced redox capacity; meanwhile, facile polarized charge transfer in the cationic network may enable rapid kinetics. This two-prong approach could endow additional high-rate capacitance to a transition metal oxide.

Commercial rechargeable Li-ion batteries have excellent energy densities $\left(E_{\mathrm{S}} \sim 100-250 \mathrm{~W} \mathrm{~h} \mathrm{~kg}^{-1}\right)$ but inadequate power densities $\left(P_{\mathrm{S}}<0.5 \mathrm{~kW} \mathrm{~kg}^{-1}\right)$ and lifetimes (<2000 cycles) $[4,5]$. In comparison, an EC that combines the high power density of EDLC and the high redox energy density of pseudocapacitor would be very promising. This prospect has driven recent advances in aqueous ECs by engineering either electrode nanostructures or electrode redox reactions [6-13]. The first approach seeks to increase electrochemical activities and decrease internal electric loss by using, e.g., carbon electrodes with sub-nanometer pores or nano-fibers $[14,15]$. The second approach seeks to employ transition metal oxides traditionally reserved for aqueous batteries (e.g., $\mathrm{MnO}_{2}, \mathrm{NiO}$ and $\mathrm{RuO}_{2}$ ) to enable pseudocapacitor mechanisms [16]. However, neither approach has succeeded in reaching the target with Li-ion batteries' energy density and supercapacitors' power density.

Titania has been extensively studied as a photocatalyst

${ }^{1}$ State Key Laboratory of High Performance Ceramics and Superfine Microstructures, Shanghai Institute of Ceramics, Chinese Academy of Sciences, Shanghai 200050, China

${ }^{2}$ Department of Materials Science and Engineering, University of Pennsylvania, Pennsylvania, PA 19104-6272, USA

${ }^{3}$ State Key Laboratory of Rare Earth Materials Chemistry and Applications and National Laboratory, College of Chemistry and Molecular Engineering, Peking University, Beijing 100871, China

${ }^{4}$ College of Chemistry and Molecular Engineering, Zhengzhou University, Zhengzhou 450001, China

* Corresponding author (email: huangfq@mail.sic.ac.cn) 
and anode in dye-sensitized solar cells $[17,18]$. The recent discovery of highly conductive reduced $\mathrm{TiO}_{2}-$ also an excellent photocatalyst $[19,20]$ with remarkable microwave absorption [21-24], and supercapacitor-like Li storage [25], naturally portends its use in ECs. Indeed, conducting $\mathrm{TiO}_{2}$ whiskers grown on conducting carbon mats have been used to support a $\mathrm{MnO}_{2}$ redox electrode and a nanostructured carbon electrode in an asymmetrically-structured EC [6]. But as an active material with surface redox reactions, nanostructured $\mathrm{TiO}_{2}$ itself only features a modest capacitance [26]. We nevertheless chose titania to study because of its low density and structure; we also viewed the corner-connected $\mathrm{TiO}_{6}$ octahedral network favorable for high conductivity since it should remain stable and connected even after substantial $\mathrm{O}^{2-}$ removal and $\mathrm{N}^{3-}$ substitution.

Herein, a N-doped black titania $\left(\mathrm{TiO}_{2-x}: \mathrm{N}\right)$ in a $\mathrm{H}_{2} \mathrm{SO}_{4}$ electrolyte can indeed provide high specific capacitance via rapid $\mathrm{N}$-mediated redox reactions $\left(\mathrm{TiO}_{2-x} \mathrm{~N}_{y}+z \mathrm{H}^{+}+\right.$ $z \mathrm{e}^{-} \leftrightarrow \mathrm{TiO}_{2-x} \mathrm{~N}_{y} \mathrm{H}_{z}$ ), especially in acidic solutions, providing a specific capacitance of $750 \mathrm{Fg}^{-1}$ at $2 \mathrm{mV} \mathrm{s}^{-1}$ (707 $\mathrm{F} \mathrm{g}^{-1}$ at $\left.1 \mathrm{~A} \mathrm{~g}^{-1}\right)$, fast charging/discharging (503 $\mathrm{F} \mathrm{g}^{-1}$ at $\left.20 \mathrm{~A} \mathrm{~g}^{-1}\right)$, and maintain stable after initial fading (75\% after 2000 cycles).

\section{EXPERIMENTAL SECTION}

\section{Materials}

Preparation of black titania electrodes is schematically illustrated in Fig. S1. Preparation of $\mathrm{TiO}_{2-x}$ and $\mathrm{TiO}_{2-x}: \mathrm{N}$ was described elsewhere [19,27]. Briefly, titania powders were precipitated from a $\mathrm{TiCl}_{4}$ (Alpha Aesar) solution by adjusting $\mathrm{pH}$ to reach 7 , followed by freeze-drying and grinding. The powders were reduced at $550^{\circ} \mathrm{C}$ by molten $\mathrm{Al}$, in vacuum $\left(5 \times 10^{-4} \mathrm{~Pa}\right)$, then partially nitridized at $500^{\circ} \mathrm{C}$ for $4 \mathrm{~h}$ in $\mathrm{NH}_{3}(300 \mathrm{sccm})$ to obtain $\mathrm{TiO}_{2-x}: \mathrm{N}$. Graphene foam was grown by chemical vapor deposition on a fugitive nickel foam-later removed by $0.5 \mathrm{~mol} \mathrm{~L}^{-1}$ $\mathrm{HCl}$ etching, as free-standing three-dimensional (3D)graphene foam [28].

\section{Material characterizations}

Transmission electron microscopy (TEM), scanning TEM (STEM), and selected area electron diffraction (SAED) were conducted using a Tecnai-F20 microscope (FEI Co., USA) at $200 \mathrm{kV}$. Scanning electron microscopy (SEM) was conducted using a Supra 55 microscope (Carl Zeiss, Germany) at $1 \mathrm{kV}$. X-ray diffraction (XRD) patterns were obtained using a Bruker diffractometer (D8 FOCUS) at $40 \mathrm{kV}$ and $40 \mathrm{~mA}$ with $\mathrm{Cu} \mathrm{Ka}$ radiation $(\lambda=0.15418 \mathrm{~nm})$.
X-ray photoelectron spectroscopy (XPS) was performed in an RBD upgraded PHI-5000C ESCA system (Perkin Elmer) with $\mathrm{Mg} \mathrm{Ka}$ radiation $(h v=1253.6 \mathrm{eV})$. Electron paramagnetic resonance (EPR) spectra were collected using a Bruker EMX-8 spectrometer at $9.44 \mathrm{GHz}$ at $300 \mathrm{~K}$. Magnetization versus magnetic field $(M-H)$ was measured in a Physical Property Measurement System (Quantum Design).

\section{Electrochemical characterization}

Electrochemical measurements were conducted using an electrochemical workstation (CHI 760E). Properties of the active material (titania) were measured using threeelectrode aqueous cells with a titania working electrode (embedded in a 3D-graphene current collector), a Pt counter electrode $(45 \mathrm{~mm} \times 10 \mathrm{~mm} \times 1 \mathrm{~mm})$ and an $\mathrm{Ag} /$ $\mathrm{AgCl}$ reference electrode (Fig. S1 in Supplementary information).

\section{Calculation of electrochemical properties}

When the electrode contained a non-titania current collector (e.g., 3D-graphene), its weight was measured with and without titania loading. The weight of the active material $\left(M_{\mathrm{TiO}_{2}}\right)$ of the electrode was calculated using Equation (1),

$M_{\mathrm{TiO}_{2}}=M_{\text {electrode }}-M_{\text {collector }}$,

where $M_{\text {electrode }} / M_{\text {collector }}$ are the weights of the loaded electrode and unloaded current collector, respectively.

The capacitance $\left(C\right.$, in $\left.\mathrm{F} \mathrm{g}^{-1}\right)$ from cyclic voltammetry (CV) curves at different sweep rates was calculated using Equation (2)

$C=A / 2 m v V$,

where $A$ is the integrated area of the CV loop (in W), $m$ is the mass of active materials, $v$ is the sweep rate (in $\mathrm{V} \mathrm{s}^{-1}$ ), and $V$ (in $\mathrm{V}$ ) is the width of the potential window.

The capacitances from the galvanostatic (CC) curves at different current densities were calculated using Equation (3)

$C=i t / m V$,

where $i$ is the current applied (in A), $t$ is the discharge time (in s), and $V$ is the width of the potential window. The blank electrode without active materials was also tested under the same condition, which was deducted for calculating the specific capacitance of the active materials.

\section{RESULTS AND DISCUSSION}

$\mathrm{N}$-doped black titania, $\mathrm{TiO}_{2-x}: \mathrm{N}$, by annealing/doping (in flowing $\mathrm{NH}_{3}$ ) a black titania (referred to as $\mathrm{TiO}_{2-x}$ ) pre- 
pared from a low-cost, scalable aluminum-reduction process [19]. The as-obtained $\mathrm{TiO}_{2-x}: \mathrm{N}$ has a high surface-area, $263 \mathrm{~m}^{2} \mathrm{~g}^{-1}$, and can be easily incorporated into electrodes and ECs as shown in Fig. S1. Nominally nanocrystalline anatase according to XRD (Fig. 1a), both $\mathrm{TiO}_{2-x}: \mathrm{N}$ and $\mathrm{TiO}_{2-x}$ crystallites actually have an amorphous shell (Fig. 1b) [20]. In $\mathrm{TiO}_{2-x}$, the amorphous shell presumably formed when the anatase lattice collapsed to relieve the strain from $\mathrm{O}^{2-}$ depletion and $\mathrm{Ti}^{4+} / \mathrm{Ti}^{3+}$ conversion. While amorphous structure does not necessarily enhance electrochemical activity, we found it makes $\mathrm{N}^{3-}$ substitution easier in forming $\mathrm{TiO}_{2-x}: \mathrm{N}$. High resolution transmission electron microscopy (HRTEM) images revealed $\mathrm{TiO}_{2-x}: \mathrm{N}$ powders as agglomerates of $\sim 10-20 \mathrm{~nm}$ near-spherical nanoparticles with an amorphous shell of $\sim 2 \mathrm{~nm}$ thick, which would constitute $50 \%-80 \%$ of the particle volume. To discern the nanostructure, the sameregion imaging was performed using high angle annular dark-field STEM (HAADF-STEM), as shown in Fig. 1c and e, and dark-field TEM (DF-TEM), as shown in
Fig. $1 \mathrm{~d}$ and $\mathrm{f}$. The HAADF-STEM images show scattered low-density regions (porous pockets) of various sizes most likely 3D distribution (Fig. 1c, e). The corresponding DF-TEM images suppress the contrast in the crystalline cores and highlight the amorphous surface layer (Fig. 1d, f). In DF-TEM, by selecting a specific diffraction axis in the SAED, the core being a single crystal shows a dark contrast while the amorphous shell with random short-range order reveals random bright points (see Fig. 1d). Lastly, by selecting all the diffraction axes in the SAED (Fig. 1g), the DF-TEM image shows a fuzzy amorphous shell surrounding a (colored according to crystalline orientation) crystalline core with some sharp edges (Fig. 1f). Thus, the overall impression is porously packed, crystalline-core/amorphous-shell, nanoparticles.

The concentration of $\mathrm{N}$ in $\mathrm{TiO}_{2-x}: \mathrm{N}$ determined by XPS (Fig. 2a) was 9.29 at.\%. According to O 1s XPS, the surface of $\mathrm{TiO}_{2-x}: \mathrm{N}$ has a lower level of oxidation and/or $\mathrm{O} / \mathrm{OH}$ adsorption than $\mathrm{TiO}_{2-x}$ (Fig. 2b). On the other hand, while $\mathrm{Ti} 2 \mathrm{p}$ XPS indicates increased $\mathrm{Ti}^{3+}$ (and
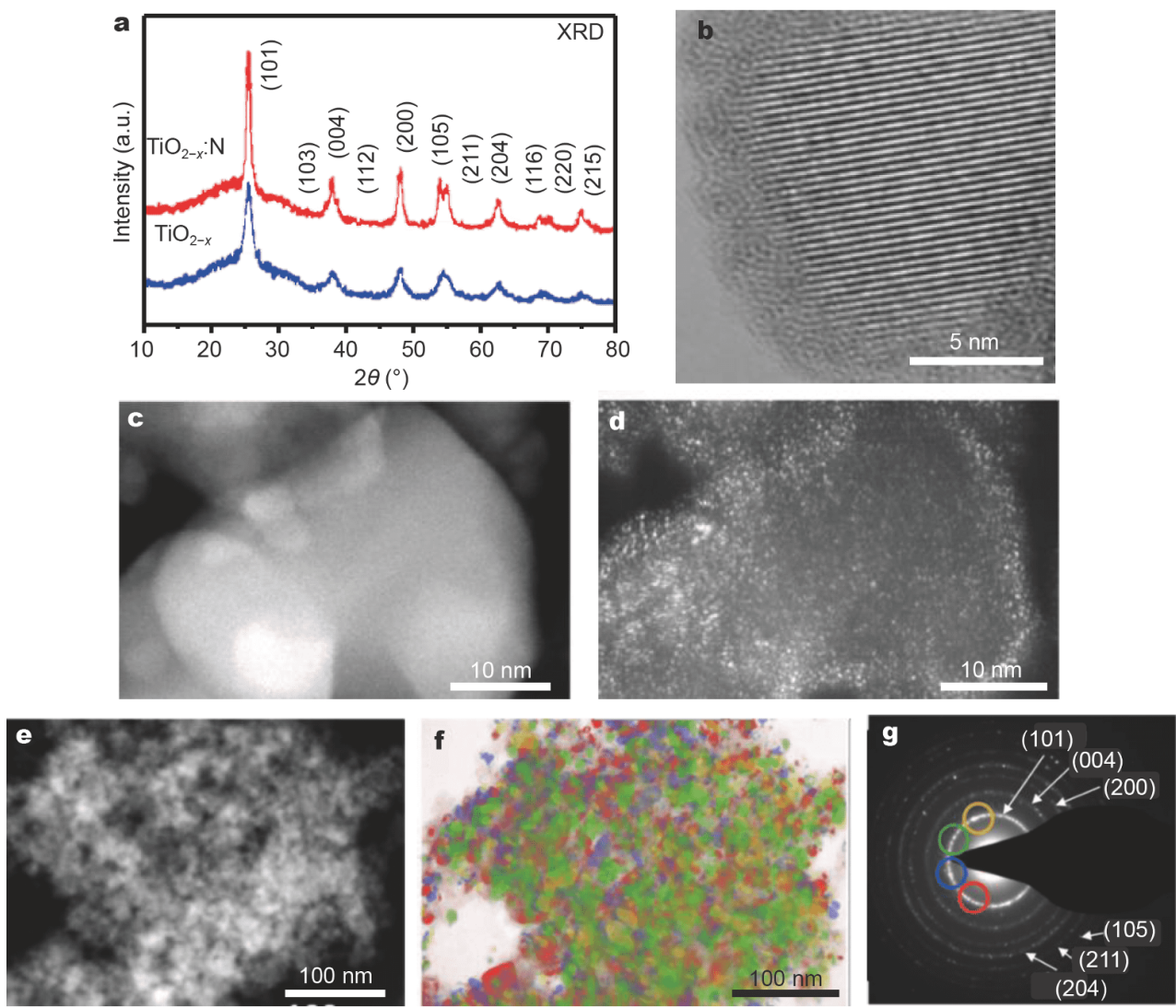

Figure 1 Structure and nanostructure. (a) XRD patterns of Al-reduced titania before $\left(\mathrm{TiO}_{2-x}\right)$ and after $\left(\mathrm{TiO}_{2-x}: \mathrm{N}\right)$ nitrogen doping. (b) HRTEM image. (c) HAADF-STEM image of $\mathrm{TiO}_{2-x}: \mathrm{N}$. (d) High resolution DF-TEM image for the same region as (c). (e) HAADF-STEM image of TiO ${ }_{2-x}: \mathrm{N}$ at a lower magnification. (f) DF-TEM image for the same region as (e), with different crystallite orientations indicated by different colors according to the SAED pattern in $(\mathrm{g})$. 

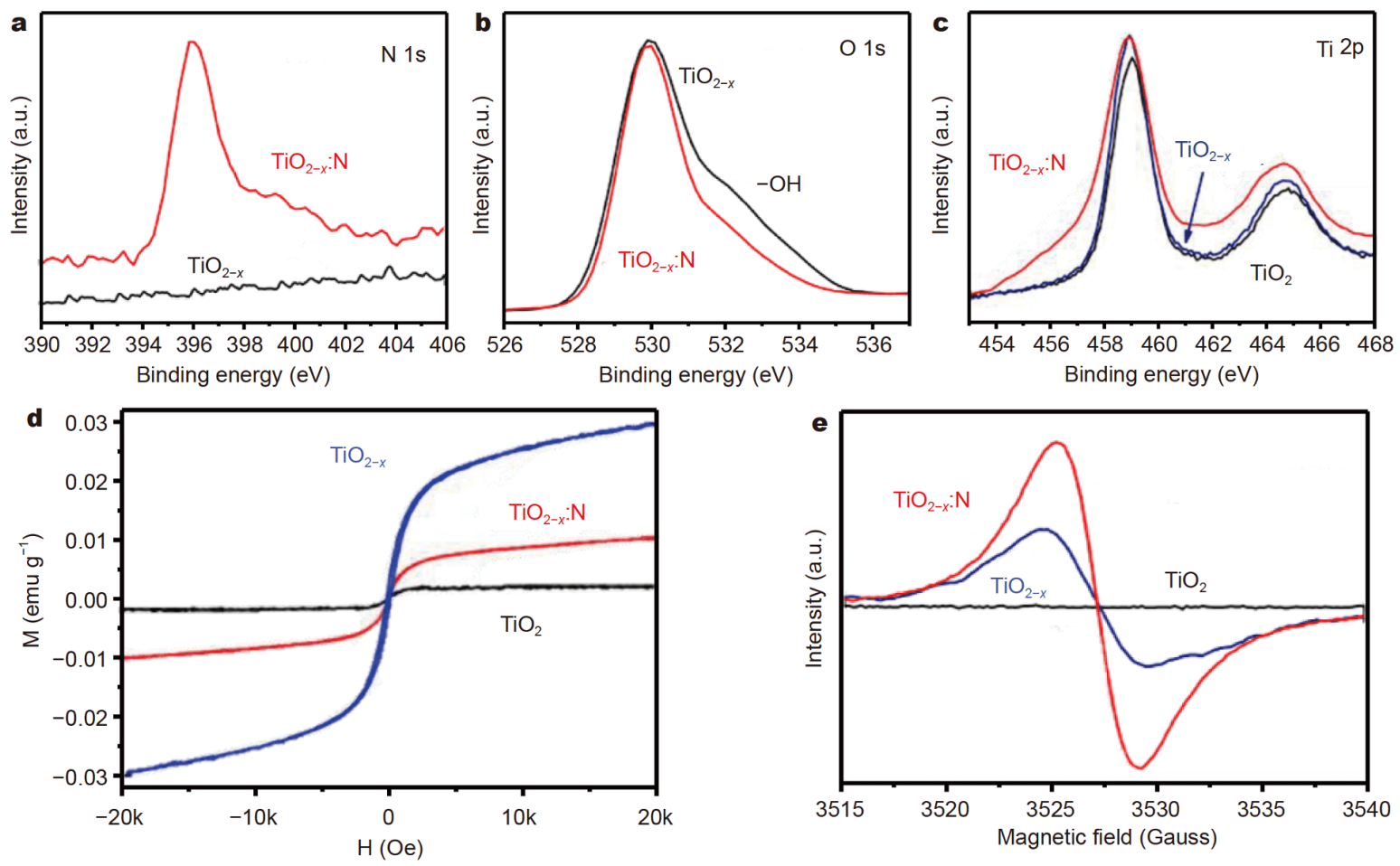

Figure 2 XPS, magnetic hysteresis and EPR spectra of $\mathrm{TiO}_{2}, \mathrm{TiO}_{2-x}$ and $\mathrm{TiO}_{2-x}: \mathrm{N}$. (a) $\mathrm{N}$ 1s and (b) O 1s core-level XPS of titania powder before (TiO $)$ and after Al-reduction $\left(\mathrm{TiO}_{2-x}\right)$, and after further nitrogen doping $\left(\mathrm{TiO}_{2-x}: \mathrm{N}\right)$. Main peak in $\mathrm{O} 1 \mathrm{~s}$ XPS around $529.9 \mathrm{eV}$ is assigned to Ti-O bonds, and shoulder at around $532 \mathrm{eV}$ is due to adsorbed hydroxyl groups. (c) Ti $2 \mathrm{p}$ XPS of $\mathrm{TiO}_{2}, \mathrm{TiO}_{2-x}$, and $\mathrm{TiO}_{2-x}: \mathrm{N}$, and their de-convolutions. Same spectra of $\mathrm{TiO}_{2-x}$ and $\mathrm{TiO}_{2}$ suggest surface oxidation of $\mathrm{Ti}^{3+}$ (and possibly some $\mathrm{Ti}^{2+}$ ) due to exposure to atmospheric $\mathrm{O}_{2}$ and $\mathrm{H}_{2} \mathrm{O}$. (d) $M-H$ and (e) $\mathrm{EPR}$ spectra of $\mathrm{TiO}_{2}, \mathrm{TiO}_{2-x}$, and $\mathrm{TiO}_{2-x}: \mathrm{N}$ showing $\mathrm{TiO}_{2-x}: \mathrm{N}$ being intermediate between $\mathrm{TiO}_{2}$ and $\mathrm{TiO}_{2-x}$.

possibly some $\mathrm{Ti}^{2+}$ ) concentration on $\mathrm{TiO}_{2-x}: \mathrm{N}$ compared with $\mathrm{TiO}_{2}$ (Fig. 2c), $\mathrm{TiO}_{2-x}$ has the same surface concentration of $\mathrm{Ti}^{3+}$ (possibly including some $\mathrm{Ti}^{2+}$ ) as $\mathrm{TiO}_{2}$. This suggests that surface oxidation may have occurred when the samples were exposed to the ambient air; as a result, the difference between different forms of titania is obliterated. A more definitive bulk-representing measure of $\mathrm{Ti}^{3+}$ comes from its magnetic signature. Relative to $\mathrm{TiO}_{2}$ and $\mathrm{TiO}_{2-x}, \mathrm{TiO}_{2-x}: \mathrm{N}$ has an intermediate magnetization (Fig. 2d) and EPR spectrum (Fig. 2e, the data is normalized by the weights of samples), both due to paramagnetic $\mathrm{Ti}^{3+}$. The data of bulk transport measurement shown in Table S1 further indicates that $\mathrm{TiO}_{2-x}: \mathrm{N}$ has a lower carrier concentration than $\mathrm{TiO}_{2-x}$, but a higher conductivity because of the higher carrier mobility $\left(\mathrm{TiO}_{2}\right.$ was too resistive to measure at room temperature). Since (a) $\mathrm{NH}_{3}$ atmosphere having a partial pressure of hydrogen can cause reduction, while $\mathrm{N}^{3-}$ substitution of $\mathrm{O}^{2-}$ can be charge-compensated by either (b) $\mathrm{Ti}^{3+}$ to $\mathrm{Ti}^{4+}$ conversion (oxidation) or (c) oxygen vacancy creation, and both higher oxygen vacancies and higher carrier concentrations will lower the mobility, our $\mathrm{TiO}_{2-x}: \mathrm{N}$ re- sults of net $\mathrm{Ti}^{3+} \rightarrow \mathrm{Ti}^{4+}$ conversion and higher mobility suggest (b) overwhelms (a), and (c) is insignificant.

Electrochemical properties of $\mathrm{TiO}_{2-x}: \mathrm{N}, \mathrm{TiO}_{2-x}$, and $\mathrm{TiO}_{2}$ were measured in a three-electrode cell with a $\mathrm{Pt}$ counter electrode and an $\mathrm{Ag} / \mathrm{AgCl}$ reference electrode (Fig. S1). A small amount of carbon black was used to improve the inter-particle contact of $\mathrm{TiO}_{2-x}: \mathrm{N}$ and to reduce the electrode resistance, and a 3D-graphene foam was used as the current collector [28] (Unless otherwise noted, containing $0.5 \mathrm{mg} \mathrm{TiO}{ }_{2-x}: \mathrm{N}$ in each electrode. See EXPERIMENTAL SECTION for sample details, symbol definitions and data calculations). To avoid $\mathrm{H}_{2}$ (at $<0 \mathrm{~V}_{\mathrm{RHE}}=$ reversible hydrogen electrode voltage) and $\mathrm{O}_{2}$ evolutions (at $>1.23 \mathrm{~V}_{\mathrm{RHE}}$ ) from water, we selected the following voltage windows: $\sim 0.2-0.9 \mathrm{~V}_{\mathrm{RHE}}$ at $\mathrm{pH} 0$ $\left(0.5 \mathrm{~mol} \mathrm{~L}^{-1} \quad \mathrm{H}_{2} \mathrm{SO}_{4} \quad\right.$ solution), corresponding to $0-0.7 \mathrm{~V}_{\mathrm{Ag} / \mathrm{AgCl}}$. The dramatic improvement of $\mathrm{TiO}_{2-x}: \mathrm{N}$ over $\mathrm{TiO}_{2}$ is evident from the CV plots (Fig. 3a) at $\mathrm{pH} 0$ at $2 \mathrm{mV} \mathrm{s}^{-1}$ : a specific capacitance $C_{\mathrm{S}}$ of $750 \mathrm{~F} \mathrm{~g}^{-1}$ for $\mathrm{TiO}_{2-x}$ : $\mathrm{N}$, vs. $15 \mathrm{~F} \mathrm{~g}^{-1}$ for $\mathrm{TiO}_{2}$ and $240 \mathrm{~F} \mathrm{~g}^{-1}$ for $\mathrm{TiO}_{2-x}$. At other scan rates $\left(5-100 \mathrm{mV} \mathrm{s}^{-1}\right)$, the $\mathrm{TiO}_{2-x}: \mathrm{N}$ electrode also performed well (Fig. 3b and d upper), giving $665 \mathrm{~F} \mathrm{~g}^{-1}$ at 

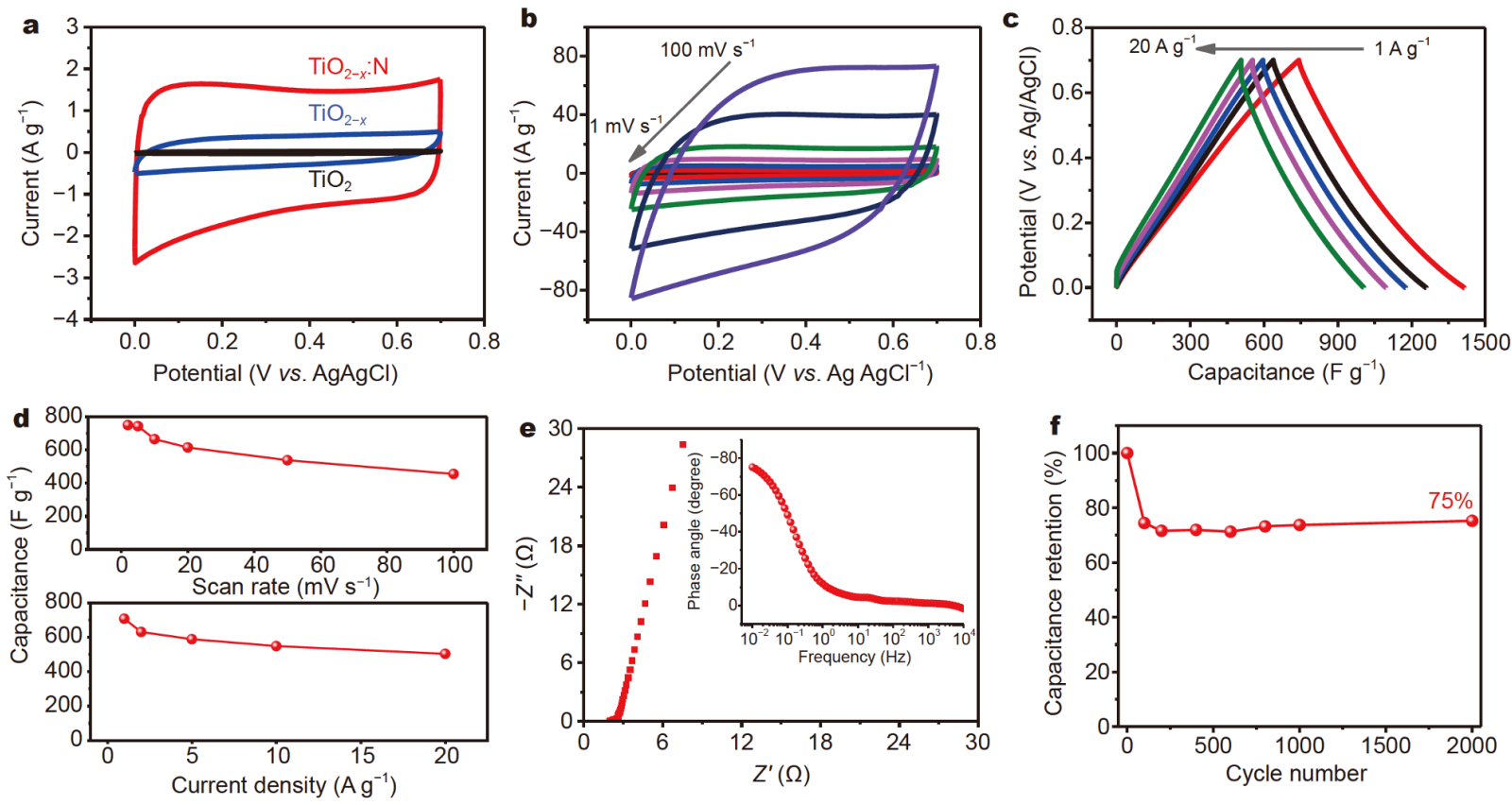

Figure 3 Electrochemical performance. (a) CV curves of $\mathrm{TiO}_{2-x}: \mathrm{N}$ and $\mathrm{TiO}_{2-x}$ scanned at $2 \mathrm{mV} \mathrm{s}^{-1}$ in $0.5 \mathrm{~mol} \mathrm{~L}^{-1} \mathrm{H}_{2} \mathrm{SO}_{4}$ aqueous electrolyte. TiO shows no activity. (b) Rate capability spanning over 2 to $100 \mathrm{mV} \mathrm{s}^{-1}$. (c) Galvanostatic charge/discharge (CC) curves of TiO $\mathrm{Ti}_{2-x}: \mathrm{N}$ electrode measured at 1-20 mA (1-20 A g ${ }^{-1}$ ). (d) Rate capability spanning over 1 to $20 \mathrm{~A} \mathrm{~g}^{-1}$ and 2-100 mV s${ }^{-1}$. (e) Cole-Cole plot of complex impedance of TiO ${ }_{2-x}: \mathrm{N}$ electrode, with frequency marked at two locations. Inset: phase angle versus frequency. (f) Retained capacitances of $\mathrm{TiO}_{2-x}: \mathrm{N}^{\text {in }} 0.5 \mathrm{~mol} \mathrm{~L}^{-1} \mathrm{H}_{2} \mathrm{SO}_{4}$ after $2000 \mathrm{CV}$ cycles at a scan rate of $100 \mathrm{mV} \mathrm{s}^{-1}$.

$10 \mathrm{mV} \mathrm{s}^{-1}$ and $455 \mathrm{Fg}^{-1}$ at $100 \mathrm{mV} \mathrm{s}^{-1}$. The specific capacitance was further determined from the galvanostatic charge/discharge (CC) plot (Fig. 3c), giving $707 \mathrm{~F} \mathrm{~g}^{-1}$ at $1 \mathrm{~A} \mathrm{~g}^{-1}$. At a very high current density of $20 \mathrm{~A} \mathrm{~g}^{-1}$ (Fig. 3c and $\mathrm{d}$ below), the CC curve at a charge/discharge time of $\sim 17$ s (typically achievable only in high-rate double-layer capacitors) still features a capacitance of $503 \mathrm{~F} \mathrm{~g}^{-1}$. Furthermore, from the CC curve's voltage discontinuity of $1.1 \mathrm{mV}$ (an enlarged view in Fig. S2) at $1 \mathrm{~A} \mathrm{~g}^{-1}$ (actual current is $0.5 \mathrm{~mA}$ ), we obtained an equivalent series resistance (ESR) of $\sim 2.2 \Omega$. Thus, the high-rate capacitance of $\mathrm{TiO}_{2-x}: \mathrm{N}$ electrodes is outstanding, especially in acidic environments.

Dynamic EIS further confirms fast electrochemical kinetics of $\mathrm{TiO}_{2-x}: \mathrm{N}$ electrodes. Unlike $\mathrm{TiO}_{2}$ and $\mathrm{TiO}_{2-x}$ electrodes of a higher DC resistance and lower capacitance (Fig. S3), the $\mathrm{TiO}_{2-x}: \mathrm{N}$ electrode displays a purely capacitive behavior in the Cole-Cole plot (Fig. 3e) with a small complex impedance above $\sim 10 \mathrm{~Hz}$. The plateau phase angle of $-75^{\circ}$ at $0.01 \mathrm{~Hz}$ indicates a close-to-ideal capacitor (inset in Fig. 3e), and the characteristic frequency $f_{0}=0.12 \mathrm{~Hz}$ at $-45^{\circ}$ when resistive impedance equals capacitive impedances gives a time constant $\tau_{0}=1 / f_{0}$ of $8.3 \mathrm{~s}$. (Activated-carbon ECs have $\tau_{0} \sim 10 \mathrm{~s}$ [29], and Ndoped few-layer graphene has $\tau_{0} \sim 2.1 \mathrm{~s}$ ) [3]. At the high- frequency limit (e.g., $10 \mathrm{kHz}$ ), the real-part impedance of $2 \Omega$ matches the ESR estimated from the CC curve $(2.2 \Omega)$. Cycling performance was also evaluated: at $100 \mathrm{mV} \mathrm{s}^{-1}$, the CV curves in $0.5 \mathrm{~mol} \mathrm{~L}^{-1} \mathrm{H}_{2} \mathrm{SO}_{4}$ electrolyte suffer a fast initial fading but remain stable after then, retaining $75 \%$ of the initial capacitances after 2000 cycles. The fast fading at the beginning may be due to the $\mathrm{N}$ loss, as explained later. Table 1 compares the performance of the $\mathrm{TiO}_{2}$-based supercapacitors. Obviously, although most of the $\mathrm{TiO}_{2}$-based supercapacitors prepared by insitu oxidation of Ti foil/mesh show high surface capacitances, the workability is also limited. Differently, $\mathrm{TiO}_{2-x}$ : $\mathrm{N}$ powder can be used easily and exhibits excellent performance.

In our previous study of $\mathrm{N}$-doped few-layer carbon, $\mathrm{N}$ is covalently bonded to the $\mathrm{C}$ network and thus permanently attached to the latter. To investigate the stability of $\mathrm{N}$ in $\mathrm{TiO}_{2-x}: \mathrm{N}$, we held it at the maximum potential of the electrochemical test (see below) for various times, then checked its XPS signal (Fig. $4 \mathrm{a}-\mathrm{c}$ ). Indeed, after the first $24 \mathrm{~h}$ during which some $\mathrm{N}$ was lost (Fig. 4a), while subsequent XPS and EPR spectra all showed little change after many days (Fig. $4 \mathrm{a}-\mathrm{c}, \mathrm{d}$ ). Therefore, the nitridized product is stable in the electrochemical environment of active ECs. Moreover, after holding the electrode at $0.7 \mathrm{~V}$, 
Table 1 Performance comparison of the $\mathrm{TiO}_{2}$-based supercapacitors

\begin{tabular}{|c|c|c|c|}
\hline Electrode materials & Specific capacitance & Electrolyte & Ref. \\
\hline $\mathrm{TiO}_{2-x}: \mathrm{N}$ & $\begin{array}{l}750 \mathrm{Fg}^{-1} @ 2 \mathrm{mV} \mathrm{s}^{-1} \\
707 \mathrm{Fg}^{-1} @ 1 \mathrm{~A} \mathrm{~g}^{-1}\end{array}$ & $0.5 \mathrm{~mol} \mathrm{~L}^{-1} \mathrm{H}_{2} \mathrm{SO}_{4}$ & This work \\
\hline $\begin{array}{c}\mathrm{TiO}_{2} \text { nanotube array } \\
\mathrm{TiO}_{2} \text { nanoribbon-nanotube } \\
\mathrm{TiO}_{2} \text { nanowire-nanotube }\end{array}$ & $\begin{array}{l}3.113 \mathrm{mF} \mathrm{cm}^{-2} @ 10 \mu \mathrm{A} \mathrm{cm}^{-2} \\
1.394 \mathrm{mF} \mathrm{cm}^{-2} @ 10 \mu \mathrm{A} \mathrm{cm}^{-2} \\
0.539 \mathrm{mF} \mathrm{cm}^{-2} @ 10 \mu \mathrm{Acm}^{-2}\end{array}$ & $1.0 \mathrm{~mol} \mathrm{~L}^{-1} \mathrm{H}_{2} \mathrm{SO}_{4}$ & [30] \\
\hline $\begin{array}{l}\mathrm{TiO}_{2} \text { nanotube } \\
\mathrm{TiO}_{2} \text { powder }\end{array}$ & $\begin{array}{l}911 \mu \mathrm{F} \mathrm{cm}^{-2} @ 1 \mathrm{mV} \mathrm{s}^{-1} \\
181 \mu \mathrm{F} \mathrm{cm}^{-2} @ 1 \mathrm{mV} \mathrm{s}^{-1}\end{array}$ & $1 \mathrm{~mol} \mathrm{~L}^{-1} \mathrm{KCl}$ & [31] \\
\hline $\mathrm{TiO}_{2-x}$ nanotube & $900 \mu \mathrm{F} \mathrm{cm}{ }^{-2} @ 1 \mathrm{mV} \mathrm{s}^{-1}$ & $1 \mathrm{~mol} \mathrm{~L}^{-1} \mathrm{KCl}$ & {$[32]$} \\
\hline Hydrogenated $\mathrm{TiO}_{2}$ nanotube & $\begin{array}{l}14.95 \mathrm{mF} \mathrm{cm} \mathrm{cm}^{-2} @ 10 \mathrm{mV} \mathrm{s}^{-1} \\
3.24 \mathrm{mF} \mathrm{cm} \mathrm{mV} \mathrm{s}^{-2} @ 100\end{array}$ & $0.5 \mathrm{~mol} \mathrm{~L}^{-1} \mathrm{Na}_{2} \mathrm{SO}_{4}$ & [26] \\
\hline $\begin{array}{c}\mathrm{H}-\mathrm{TiO}_{2} @ \mathrm{C} \\
\mathrm{TiO}_{2} @ \mathrm{C}\end{array}$ & $\begin{array}{l}253.4 \mathrm{~F} \mathrm{~g}^{-1} @ 10 \mathrm{mV} \mathrm{s}^{-1} \\
197.1 \mathrm{Fg}^{-1} @ 10 \mathrm{mV} \mathrm{s}^{-1}\end{array}$ & $5 \mathrm{~mol} \mathrm{~L}^{-1} \mathrm{LiCl}$ & [5] \\
\hline Nitrided $\mathrm{TiO}_{2}$ nanoparticle & $85.7 \mathrm{mF} \mathrm{cm}{ }^{-2} @ 10 \mathrm{mV} \mathrm{s}^{-1}$ & $0.5 \mathrm{~mol} \mathrm{~L}^{-1} \mathrm{Na}_{2} \mathrm{SO}_{4}$ & {$[33]$} \\
\hline $\begin{array}{c}\mathrm{TiO}_{2} \text { nanotube } \\
\mathrm{TiO}_{2} / \mathrm{Nb}_{2} \mathrm{O}_{5} \text { nanotube } \\
\text { Nitrided } \mathrm{TiO}_{2} / \mathrm{Nb}_{2} \mathrm{O}_{5} \text { nanotube }\end{array}$ & $\begin{array}{c}158 \mu \mathrm{F} \mathrm{cm}^{-2} @ 1 \mathrm{mV} \mathrm{s}^{-1} \\
1536 \mu \mathrm{F} \mathrm{cm} \mathrm{cm}^{-2} @ 1 \mathrm{mV} \mathrm{s}^{-1} \\
37 \mathrm{mF} \mathrm{cm}^{-2} @ 1 \mathrm{mV} \mathrm{s}^{-1}\end{array}$ & $1.0 \mathrm{~mol} \mathrm{~L}^{-1} \mathrm{H}_{2} \mathrm{SO}_{4}$ & [35] \\
\hline $\mathrm{TiO}_{2}$ nanocrystals & $146 \mathrm{Fg}^{-1} @ 0.2 \mathrm{~A} \mathrm{~g}^{-1}$ & $1 \mathrm{~mol} \mathrm{~L}^{-1} \mathrm{KOH}$ & [35] \\
\hline Ti-rich $\mathrm{TiO}_{2}$ & $3.8 \mathrm{mF} \mathrm{cm}{ }^{-2} @ 25 \mu \mathrm{Acm}^{-2}$ & $0.5 \mathrm{~mol} \mathrm{~L}^{-1} \mathrm{Na}_{2} \mathrm{SO}_{4}$ & [36] \\
\hline $\mathrm{TiO}_{2-x} / \mathrm{Ti}$ & $81.75 \mathrm{mF} \mathrm{cm}^{-2} @ 2 \mathrm{mV} \mathrm{s}^{-1}$ & $1.0 \mathrm{~mol} \mathrm{~L}^{-1} \mathrm{H}_{2} \mathrm{SO}_{4}$ & {$[37]$} \\
\hline
\end{tabular}
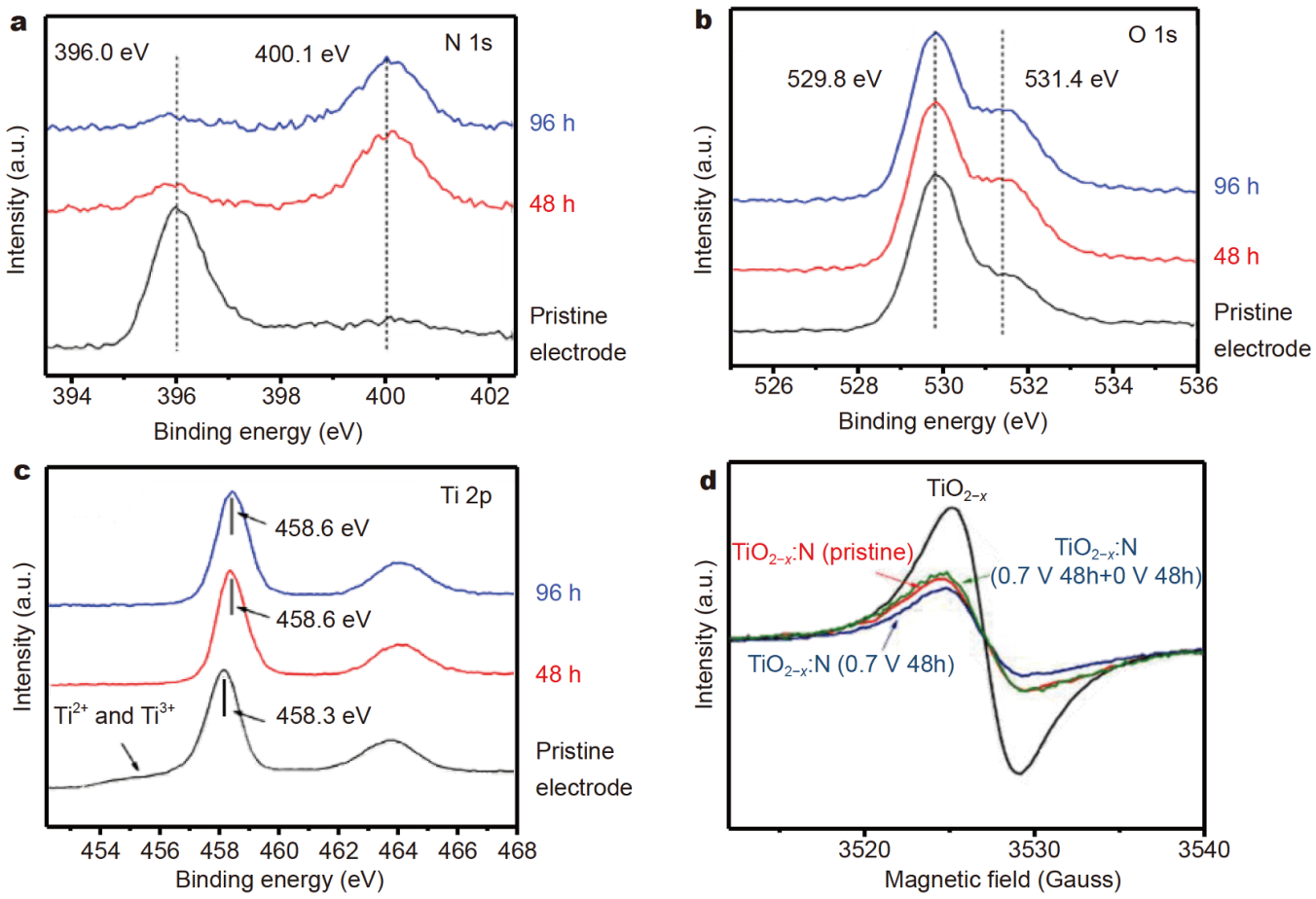

Figure 4 Mechanism investigation. (a-c) The corresponding $\mathrm{N} \mathrm{1s}$, O 1s and Ti $2 \mathrm{p}$ XPS spectra of electrochemically treated $\mathrm{TiO}_{2-x}: \mathrm{N}$ electrodes. Electrodes were held at $0.7 \mathrm{~V}$ ( $v s . \mathrm{Ag} / \mathrm{AgCl}$, oxidation potential) for 48 and $96 \mathrm{~h}$. (d) EPR spectra of pristine $\mathrm{TiO}_{2-x}$ and $\mathrm{TiO}_{2-x}: \mathrm{N}$ electrodes. The latter was also electrochemically treated for up to $96 \mathrm{~h}$. Electrodes were held at $0.7 \mathrm{~V}(v s$. Ag/ $\mathrm{AgCl}$, oxidation potential) for $48 \mathrm{~h}$ and then $0 \mathrm{~V}$ for $48 \mathrm{~h}$.

the binding energy of $\mathrm{N}, \mathrm{Ti}$, and $\mathrm{O}$ increased 4.1, 0.3 and $0 \mathrm{eV}$, respectively, meaning that the main energy storage site is $\mathrm{N}^{3-}$ in $\mathrm{TiO}_{2-x}: \mathrm{N}$, which accepted protons and achieved a relatively high valence state. To be noted, the binding energy of $\mathrm{N}$ in $\mathrm{AlN}$ and $\mathrm{NaN}_{3}$ is $\sim 396$ and $400.1 \mathrm{eV}$, respectively. So we can suspect that $z$ is $2 y-3 y$ in 
$\mathrm{N}$-mediated redox reaction $\left(\mathrm{TiO}_{2-x} \mathrm{~N}_{y}+z \mathrm{H}^{+}+z \mathrm{e}^{-} \leftrightarrow\right.$ $\left.\mathrm{TiO}_{2-x} \mathrm{~N}_{y} \mathrm{H}_{z}\right)$. The calculated theoretical capacitance (molecular weight of $\mathrm{TiO}_{2-x} \mathrm{~N}_{\mathrm{y}}$ is $\sim 77.2 \mathrm{~g} \mathrm{~mol}^{-1}$ ) of the above reaction is $664-997 \mathrm{Fg}^{-1}$. Besides, some protons may form -OH (Fig. 4b) and contribute some capacitance by a subordinate reaction of $\mathrm{TiO}_{2-x}+y \mathrm{H}^{+}+y \mathrm{e}^{-} \leftrightarrow \mathrm{TiO}_{2}$ ${ }_{-x-y}(\mathrm{OH})_{y}$, which is the mechanism of the enhanced capacitance of black $\mathrm{TiO}_{2-x}$ when compared with white $\mathrm{TiO}_{2}$. Therefore, our measured capacitance of $750 \mathrm{~F} \mathrm{~g}^{-1}$ fall in between the estimated theoretical value.

\section{CONCLUSIONS}

The overall thermodynamic and kinetic results thus support our hypothesis: $\mathrm{N}$ can activate more copious and facile proton absorption/desorption reactions, and such reactions are facilitated by electron transport and $\mathrm{Ti}^{4+} /$ $\mathrm{Ti}^{3+}$ conversion throughout $\mathrm{TiO}_{2-x}: \mathrm{N}$. This simple approach has transformed titania into a promising new EC electrode material, a possibility hitherto unknown despite decades of research on closely related photon-enabled $\mathrm{TiO}_{2}$ electrochemistry. Therefore, our approach that relies on $\mathrm{N}$-doping may well find use in the future, aiding the transformation of other highly conductive matter into electrochemically materials for energy-storage applications.

\section{Received 27 February 2020; accepted 16 March 2020;} published online 21 April 2020

1 Miller JR, Simon P. Materials science: Electrochemical capacitors for energy management. Science, 2008, 321: 651-652

2 Yu G, Xie X, Pan L, et al. Hybrid nanostructured materials for high-performance electrochemical capacitors. Nano Energy, 2013, 2: $213-234$

3 Lin T, Chen IW, Liu F, et al. Nitrogen-doped mesoporous carbon of extraordinary capacitance for electrochemical energy storage. Science, 2015, 350: 1508-1513

4 Chiang YM. Building a better battery. Science, 2010, 330: 14851486

$5 \mathrm{Lu} \mathrm{X}, \mathrm{Yu}$ M, Wang G, et al. $\mathrm{H}-\mathrm{TiO}_{2} @ \mathrm{MnO}_{2} / / \mathrm{H}-\mathrm{TiO}_{2} @ \mathrm{C}$ core-shell nanowires for high performance and flexible asymmetric supercapacitors. Adv Mater, 2013, 25: 267-272

6 Fan Z, Yan J, Wei T, et al. Asymmetric supercapacitors based on graphene $/ \mathrm{MnO}_{2}$ and activated carbon nanofiber electrodes with high power and energy density. Adv Funct Mater, 2011, 21: 23662375

7 Chen PC, Shen G, Shi Y, et al. Preparation and characterization of flexible asymmetric supercapacitors based on transition-metaloxide nanowire/single-walled carbon nanotube hybrid thin-film electrodes. ACS Nano, 2010, 4: 4403-4411

8 Wang DW, Li F, Liu M, et al. 3D aperiodic hierarchical porous graphitic carbon material for high-rate electrochemical capacitive energy storage. Angew Chem Int Ed, 2008, 47: 373-376

9 Ji J, Zhang LL, Ji $\mathrm{H}$, et al. Nanoporous $\mathrm{Ni}(\mathrm{OH})_{2}$ thin film on 3D ultrathin-graphite foam for asymmetric supercapacitor. ACS Nano,
2013, 7: 6237-6243

10 Zhao X, Zhang L, Murali S, et al. Incorporation of manganese dioxide within ultraporous activated graphene for high-performance electrochemical capacitors. ACS Nano, 2012, 6: 5404-5412

11 Lu Q, Lattanzi MW, Chen Y, et al. Supercapacitor electrodes with high-energy and power densities prepared from monolithic $\mathrm{NiO} /$ Ni nanocomposites. Angew Chem Int Ed, 2011, 50: 6847-6850

$12 \mathrm{Wu}$ ZS, Wang DW, Ren W, et al. Anchoring hydrous $\mathrm{RuO}_{2}$ on graphene sheets for high-performance electrochemical capacitors. Adv Funct Mater, 2010, 20: 3595-3602

13 Augustyn V, Come J, Lowe MA, et al. High-rate electrochemical energy storage through $\mathrm{Li}^{+}$intercalation pseudocapacitance. Nat Mater, 2013, 12: 518-522

14 Chmiola J, Yushin G, Gogotsi Y, et al. Anomalous increase in carbon capacitance at pore sizes less than 1 nanometer. Science, 2006, 313: 1760-1763

15 Pech D, Brunet M, Durou H, et al. Ultrahigh-power micrometresized supercapacitors based on onion-like carbon. Nat Nanotech, 2010, 5: 651-654

16 Simon P, Gogotsi Y. Materials for electrochemical capacitors. Nat Mater, 2008, 7, 845-854

17 Fujishima A, Honda K. Electrochemical photolysis of water at a semiconductor electrode. Nature, 1972, 238: 37-38

18 Bach U, Lupo D, Comte P, et al. Solid-state dye-sensitized mesoporous $\mathrm{TiO}_{2}$ solar cells with high photon-to-electron conversion efficiencies. Nature, 1998, 395: 583-585

19 Wang Z, Yang C, Lin T, et al. Visible-light photocatalytic, solar thermal and photoelectrochemical properties of aluminium-reduced black titania. Energy Environ Sci, 2013, 6: 3007-3014

20 Wang Z, Yang C, Lin T, et al. H-doped black titania with very high solar absorption and excellent photocatalysis enhanced by localized surface plasmon resonance. Adv Funct Mater, 2013, 23: 5444-5450

21 Brezesinski T, Wang J, Polleux J, et al. Templated nanocrystalbased porous $\mathrm{TiO}_{2}$ films for next-generation electrochemical capacitors. J Am Chem Soc, 2009, 131: 1802-1809

22 Xia $\mathrm{T}$, Zhang $\mathrm{C}$, Oyler NA, et al. Hydrogenated $\mathrm{TiO}_{2}$ nanocrystals: A novel microwave absorbing material. Adv Mater, 2013, 25: 69056910

23 Green MA, Xu J, Liu H, et al. Terahertz absorption of hydrogenated $\mathrm{TiO}_{2}$ nanoparticles. Mater Today Phys, 2018, 4: 64-69

24 Green M, Van Tran AT, Smedley R, et al. Microwave absorption of magnesium/hydrogen-treated titanium dioxide nanoparticles. Nano Mater Sci, 2019, 1: 48-59

25 Green M, Xiang P, Liu Z, et al. Microwave absorption of aluminum/hydrogen treated titanium dioxide nanoparticles. J Materiomics, 2019, 5: 133-146

26 Lu X, Wang G, Zhai T, et al. Hydrogenated $\mathrm{TiO}_{2}$ nanotube arrays for supercapacitors. Nano Lett, 2012, 12: 1690-1696

27 Lin T, Yang C, Wang Z, et al. Effective nonmetal incorporation in black titania with enhanced solar energy utilization. Energy Environ Sci, 2014, 7: 967-972

28 Bi H, Huang F, Liang J, et al. Large-scale preparation of highly conductive three dimensional graphene and its applications in CdTe solar cells. J Mater Chem, 2011, 21: 17366-17370

29 Gao Q, Demarconnay L, Raymundo-Piñero E, et al. Exploring the large voltage range of carbon/carbon supercapacitors in aqueous lithium sulfate electrolyte. Energy Environ Sci, 2012, 5: 9611-9617

30 Xie Y, Fu D. Photochemical performance and electrochemical capacitance of titania nanocomplexes. Mater Res Bull, 2010, 45: $628-635$ 
31 Salari M, Aboutalebi SH, Konstantinov K, et al. A highly ordered titania nanotube array as a supercapacitor electrode. Phys Chem Chem Phys, 2011, 13: 5038-5041

32 Salari M, Konstantinov K, Liu HK. Enhancement of the capacitance in $\mathrm{TiO}_{2}$ nanotubes through controlled introduction of oxygen vacancies. J Mater Chem, 2011, 21: 5128-5133

33 Zhou H, Zhang Y. Electrochemically self-doped $\mathrm{TiO}_{2}$ nanotube arrays for supercapacitors. J Phys Chem C, 2014, 118: 5626-5636

34 Ozkan S, Nguyen NT, Hwang I, et al. Highly conducting spaced $\mathrm{TiO}_{2}$ nanotubes enable defined conformal coating with nanocrystalline $\mathrm{Nb}_{2} \mathrm{O}_{5}$ and high performance supercapacitor applications. Small, 2017, 13: 1603821

35 Heng I, Lai CW, Juan JC, et al. Low-temperature synthesis of $\mathrm{TiO}_{2}$ nanocrystals for high performance electrochemical supercapacitors. Ceramics Int, 2019, 45: 4990-5000

36 Qorbani M, Khajehdehi O, Sabbah A, et al. Ti-rich $\mathrm{TiO}_{2}$ tubular nanolettuces by electrochemical anodization for all-solid-state high-rate supercapacitor devices. ChemSusChem, 2019, 12: 40644073

37 Wang Q, Li M, Wang Z. Supercapacitive performance of $\mathrm{TiO}_{2}$ boosted by a unique porous $\mathrm{TiO}_{2} / \mathrm{Ti}$ network and activated $\mathrm{Ti}^{3+}$. RSC Adv, 2019, 9: 7811-7817

Acknowledgements This work was financially supported by the National key R\&D Program of China (2016YFB0901600), and the Key Research Program of Chinese Academy of Sciences (QYZDJ-SSWJSC013). Chen IW was supported by U.S. Department of Energy BES grant DE-FG02-11ER46814 and used the facilities (Laboratory for Research on the Structure of Matter) supported by NSF grant DMR-1120901.

Author contributions Yang C, Huang F, and Chen IW designed the experiment; Yang $\mathrm{C}$, Wang $\mathrm{X}, \mathrm{Xu}$ J, and Wang $\mathrm{Z}$ engineered the samples and the tests; Gu H performed the SEM and TEM tests. Yang C, Wang $\mathrm{X}$, and Dong $\mathrm{W}$ analyzed the data. Yang $\mathrm{C}$ and Dong $\mathrm{W}$ wrote the paper with support from Huang F. All authors contributed to the general discussion.

Conflict of interest The authors declare that they have no conflict of interest.

Supplementary information online version of the paper.

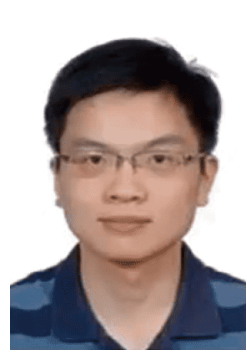

Chongyin Yang obtained his $\mathrm{PhD}$ under the supervision of Prof. Fuqiang Huang at Shanghai Institute of Ceramics of the Chinese Academy of Sciences (SICCAS). He is now an assistant research scientist at the Department of Chemistry and Biochemistry, University of Maryland. His research interests include the design, synthesis and application of supercapacitors and lithiumion batteries.

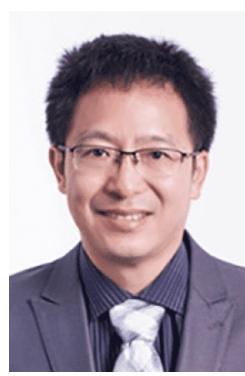

Fuqiang Huang obtained his $\mathrm{PhD}$ in science from Beijing Normal University in 1996. Then he joined the State Key Lab of High Performance Ceramics \& Superfine Microstructure at SICCAS, and became a full professor in 2003. His research interests focus on the new energy materials and devices. He put forward the concept of multiple physical quantities synergy in structure function region for energy conversion materials and the theoretical model of accumulation factor.

\section{氮掺杂黑色二氧化钛用于高性能超级电容器}

杨重寅 ${ }^{1}$, 王金金，董武杰 ${ }^{1}$, 陈一苇 ${ }^{2}$, 汪宙 ${ }^{1}$, 徐吉健 ${ }^{1}$, 林天全 ${ }^{1}$, 顾辉 ${ }^{1}$, 黄富强 $13^{*}$

摘要 对于储能系统, 同时实现高能量密度和高功率密度仍是一个 巨大的挑战. 电化学超级电容器通过表面吸附或表面氧化还原反 应实现储能, 是解决上述问题的潜在方法之一. 本论文报道了一种 新型高氮掺杂 $\left(9.29\right.$ at. \%) 黑色二氧化钛 $\left(\mathrm{TiO}_{2-x}: \mathrm{N}\right)$ 超级电容器电极 材料. 该材料具有独特的微观结构, 由高导电的非晶壳层和一个纳 米晶核组成. 在酸性电解液中, 该材料可以通过氮参与的氧化还原 反应 $\left(\mathrm{TiO}_{2-x} \mathrm{~N}_{\mathrm{y}}+z \mathrm{H}^{+}+z \mathrm{e}^{-} \leftrightarrow \mathrm{TiO}_{2-x} \mathrm{~N}_{y} \mathrm{H}_{z}\right)$ 可逆地与质子结合实现 能量的高效快速储存, 实现极高的比电容 $\left(2 \mathrm{mV} \mathrm{s}^{-1}\right.$ 扫速下容量高 达750 $\mathrm{F} \mathrm{g}^{-1}, 1 \mathrm{~A} \mathrm{~g}^{-1}$ 电流密度下容量可达 $707 \mathrm{~F} \mathrm{~g}^{-1}$ )、高倍率特性 (极高电流密度 $20 \mathrm{~A} \mathrm{~g}^{-1}$ 时容量仍可达 $503 \mathrm{~F} \mathrm{~g}^{-1}$ ) 和长时间循环下的 高稳定性. 作为一种新型超级电容器电极材料, 氮掺杂黑色二氧化 钛或将引领金属氧化物型超级电容器的复兴. 